\title{
Parental burnout: a scoping review
}

\author{
Burnout parental: revisão de escopo \\ Parental burnout: revisión del alcance
}

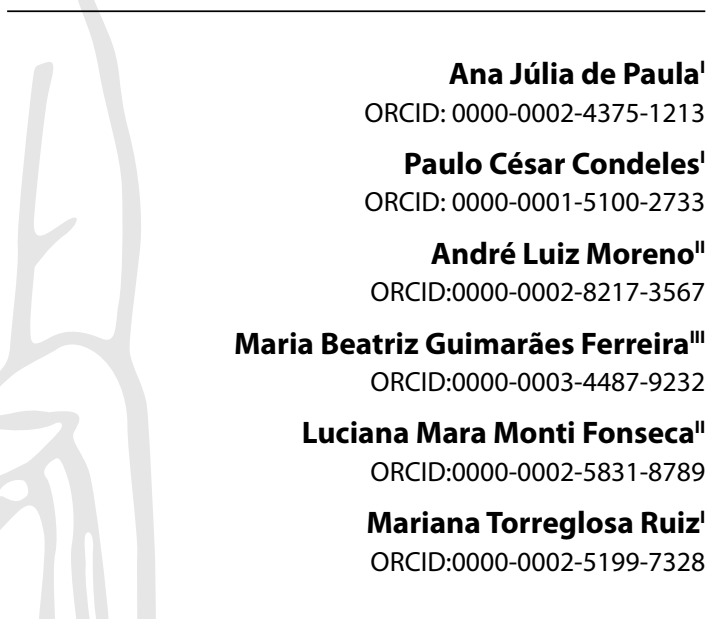

'Universidade Federal do Triângulo Mineiro. Uberaba, Minas Gerais, Brazil.

"Universidade de São Paulo. Ribeirão Preto, São Paulo, Brazil. "'Universidade Federal de Uberlândia. Uberlândia, Minas Gerais, Brazil.

How to cite this article

Paula AJ, Condeles PC, Moreno AL, Ferreira MBG, Fonseca LMM, Ruiz MT. Parental burnout: a scoping review. Rev Bras Enferm. 2022;75(Suppl 3):e20210203 https://doi.org/10.1590/0034-7167-2021-0203

Corresponding author:

Mariana Torreglosa Ruiz

E-mail: marianatorreglosa@hotmail.com

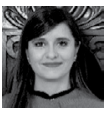

EDITOR IN CHIEF: Antonio José de Almeida Filho ASSOCIATE EDITOR: Alexandre Balsanelli

Submission: 04-18-2021

Approval: 06-29-2021

\section{ABSTRACT}

Objective: to map available evidence on parental burnout theme. Method: scoping review as according to the Joanna Briggs Institute. Search in January 2021, in six databases of publications in English, Portuguese or Spanish, without time limits. Data extracted and descriptively analyzed by three independent researchers. Results: 374 articles were identified and 20 were included in the final sample, all published in English, from 2017 onwards. Parental burnout is a complex, multifactorial problem, distinct from burnout cases, depressive symptoms and other mental health alterations. It affects 0.2 to $20 \%$ of parents, has validated and suitable instruments for measurement; if not treated, can have consequences on marital life, work relationships, child neglect and violence. Conclusions: this is a recent theme that needs to be explored, due to the possible impact on children's and families' health and on parents' work processes. Protocol registered in the Open Science Framework (https://osf.io/jd7vk). Descriptors: Parenting; Burnout, Psychological; Parental Burnout; Parents; Review.

\section{RESUMO}

Objetivo: mapear evidências disponíveis sobre a temática burnout parental. Método: revisão de escopo, conforme o Joanna Briggs Institute. Busca em janeiro de 2021, em seis bases de dados de publicações em inglês, português ou espanhol, sem delimitação de tempo. Dados extraídos e analisados descritivamente por três pesquisadores independentes. Resultados: capturados 374 artigos e incluídos 20 na amostra final, todos publicados em inglês, a partir de 2017. Burnout parental consiste em problema complexo, multifatorial, distinto dos casos de burnout, sintomas depressivos e outras alterações de saúde mental. Acomete 0,2 a 20\% dos pais, possui instrumentos validados e adequados para mensuração e, se não tratado, pode acarretar consequências na vida conjugal, relações de trabalho, negligência e violência contra a criança. Conclusões: trata-se de temática recente que necessita ser explorada, pelo possível impacto na saúde de crianças e famílias e nos processos de trabalho dos pais. Protocolo registrado no Open Science Framework (https://osf.io/jd7vk).

Descritores: Poder Familiar; Esgotamento Psicológico; Burnout Parental; Pais; Revisão.

\section{RESUMEN}

Objetivo: mapear la evidencia disponible sobre el tema del agotamiento de los padres. Método: revisión del alcance, según el Instituto Joanna Briggs. Búsqueda en enero de 2021, en seis bases de datos de publicaciones en inglés, portugués o español, sin límite de tiempo. Datos extraídos y analizados descriptivamente por tres investigadores independientes. Resultados: se capturaron 374 artículos y se incluyeron 20 en la muestra final, todos publicados en inglés, a partir de 2017. El burnout parental es un problema complejo y multifactorial, distinto de los casos de burnout, síntomas depresivos y otras alteraciones de la salud mental. Afecta entre el 0,2 y el $20 \%$ de los padres, cuenta con instrumentos de medición validados y adecuados y, si no se trata, puede tener consecuencias en la vida conyugal, las relaciones laborales, el abandono y la violencia contra el niño. Conclusiones: este es un tema reciente que necesita ser explorado, por el posible impacto en la salud de los niños y las familias y en los procesos laborales de los padres. Protocolo registrado en el Open Science Framework (https://osf.io/jd7vk).

Descriptores: Responsabilidad Parental; Agotamiento Psicológico; Burnout Parental; Padres; Revisión. 


\section{INTRODUCTION}

Parenting is how parents or caregivers take care of their children. There is no clear evidence that the genetic relationship between parents and children is significantly more advantageous when it comes to attachment. Attachment has a biological basis but is shaped by environmental and interpersonal influences rather than a genetic relationship. Therefore, parents can be considered as anyone to whom children have a strong bond of attachment ${ }^{(1)}$.

The concept of burnout emerged in scientific circles in the second half of the $20^{\text {th }}$ century and brings as defining characteristics three dimensions: physical and emotional exhaustion; depersonalization in relation to aspects of work; and ineffectiveness, which refers to incompetence, lack of achievement and productivity at work $^{(2)}$. In turn, parenting or parental responsibilities as parents in the care and upbringing of children is an exhausting work that requires time and, often at the expense of self-care deprivations, which can induce stress, make it chronic and cause physical and emotional exhaustion ${ }^{(3-4)}$. This scenario has become even more critical with the COVID-19 pandemic, which imposed stressors on the world that threaten health, safety and economic well-being, causing negative impacts on children and families ${ }^{(5)}$.

Parental burnout, like the concept of burnout, is also influenced by sociocultural and economic changes, which have made parenting more challenging and demanding for parents. The way in which children are raised, children with rights, the loss of parental authority over their children and the insertion of women in the labor market ${ }^{(6)}$ are some factors that can lead to overload and exhaustion.

Although the relationship between burnout and parenthood seemed clear, there was no precise definition in the literature and no reliable and specific means of measurement, with no record of a specific instrument for this purpose ${ }^{(6)}$. In 2017 and 2018, the first studies were conducted in Belgium, with 2,102 and in the Netherlands, with 627 parents, on the development and validation of an instrument to specifically measure parental burnout ${ }^{(6-7)}$.

Results showed that parental burnout is a distinct and specific concept, i.e., it is not related to professional burnout, depression, parental stress, depressive mood and other variables in parents ${ }^{(6-7)}$. Parental burnout is characterized by emotional exhaustion in relation to child care, emotional distancing from children, and a sense of compromised personal fulfillment related to parenting ${ }^{(5)}$. It can also be defined as a feeling of unhappiness accompanied by distancing from children and a feeling of not being 'good enough' in their role as a parent, when compared to other parents in the family's social life ${ }^{(3)}$.

Parental burnout develops in four phases, namely: contrast, when important behavioral and ideological differences between parents and children are detected; saturation, which is followed by emotional distancing with children; and exhaustion. Depletion or emotional exhaustion if not identified or treated can result in outbursts of anger, verbal and physical abuse, and neglect towards children ${ }^{(3)}$.

The following are described as precipitating factors for the development of these phases: the inability to recognize and maintain positive emotions in the relationship with children; the difficulties in structuring the environment for healthy child rearing (financial situation, family environment, among others); inability to understand the real needs of children and the development process ${ }^{(3)}$. Importantly, parental burnout is a prolonged and chronic response to the stress caused by a stressful parenting experience ${ }^{(8)}$.

The study mentioned above observed a prevalence of parental burnout in $8.8 \%$ of the sample, however, it described a worldwide prevalence of 8 to $36 \%{ }^{(6)}$. Factors such as having children with special needs; feelings of fear and anxiety about caring for young children and exacerbated self-criticism associated with the feeling of not being 'good parents' are associated with a higher occurrence of parental burnout ${ }^{(9-10)}$.

Parental burnout is a recent and little explored phenomenon, with possible negative impacts on the mental and physical health and quality of life of parents and children. It is known that factors such as having children with special needs or changes in parents' mental health can predispose to cases of parental burnout; therefore, this study focuses on analyzing the occurrence of the problem in the experience of parenting of parents and children, classified as 'healthy', analyzing the real impact of parenting on the occurrence, justifying this study.

\section{OBJECTIVE}

To map available evidence on parental burnout theme.

\section{METHODS}

\section{Study design, period, and place}

This is a scope review study, which is used to map evidence on a given phenomenon and identify existing gaps. It differs from other reviews, as it lists selection criteria based on relevance to the theme/phenomenon ${ }^{(11-13)}$. The research protocol was registered in the Open Science Framework (https://osf.io/jd7vk).

Data collection was carried out in January 2021. Databases were searched: Medline US National Library of Medicine National Institutes of Health (PubMed), Excerpta Medica DataBASE (Embase), Cumulative Index to Nursing and Allied Health Literature (CINAHL), PsycINFO - APA Psyc NET (American Psychological Association), Web of Science and Latin American and Caribbean Literature in Health Sciences (LILACS). The choice of databases was due to the amount of indexing of articles in the health area. Additional studies were included from references cited in articles extracted from primary sources (manual search).

\section{Sample, and inclusion and exclusion criteria}

The review included studies that addressed the topic of parental burnout, published in Portuguese, Spanish or English, with no time limits. Editorial-type articles, response letter, narrative literature review studies/traditional review and review methods (secondary studies) and studies that did not portray the theme were excluded. The level of evidence was not considered an exclusion criterion as it is a recent issue. Thus, 374 articles were identified in the six databases. For the elaboration of the review report, we chose to use the Preferred Reporting Items for 
Systematic Reviews and Meta-Analyses Extension for Scoping Reviews (PRISMA-ScR) Checklist ${ }^{(13)}$.

\section{Study protocol}

To prepare the review question, the five steps recommended by the Joanna Briggs Institute (JBI) $)^{(11-12,14)}$ were followed, starting with the identification of the question and moving on to the search for relevant studies, selection of studies, data extraction, grouping, summary and, finally, the presentation of results. PCC strategy [acronym for Population, Concept and Context] for formulating the review question, where $\mathrm{P}$ : parents, $\mathrm{C}$ : parental burnout, and C: parenting experience. Thus, the review question was "What is the evidence available in the literature on parental burnout in parents in the experience of parenting?".

Two reviewers, both with a PhD degree, independently performed the searches. Controlled descriptors were used from the Medical Subject Headings, "Parenting" and "Burnout Psychological" and from the Health Sciences Descriptors, "Poder familiar" and "Esgotamento Psicológico"; in both cases, it was associated with the keyword "Parental Burnout". We chose to use the word "Parental Burnout", as it was the most sensitive search strategy, enabling the mapping of the greatest number of potential references on the subject. Furthermore, it ensured enough specificity. This word is not a MeSH and/or DECS term, as it is a relatively new term and there was no description to represent it.

The MEDLINE/PubMed search strategy was used: (parenting [MeSH Terms]) AND (burnout, psychological [MeSH Terms] OR Psychological Burnout OR Burn-out Syndrome OR Burn out Syndrome OR Burnout OR Burnout Syndrome OR Burn-out OR Burn out OR Psychological Burn-out OR Burn-out, Psychological OR Psychological Burn out) AND Burnout Parental.

After standardizing this strategy, it was used for searches in other databases, being slightly modified, based on the specific criteria of each database. It is noteworthy that the descriptors were combined in different ways in order to expand the searches. Terminological variations in different languages, as well as synonyms were used to perform a sensitive search using the Boolean operators AND for simultaneous occurrence of subjects and OR for the occurrence of their respective synonyms.

\section{Descriptive analysis of results}

In the first stage, to choose the articles, the title and abstract were analyzed, followed by a full reading for the final selection, with 20 studies being extracted. Information was extracted from an instrument with items proposed by the $\mathrm{JBI}^{(15)}$, which included the identification of the article, year and place of study, methodological characteristics, assessment of methodological rigor, notes and discussions about the thematic focus of this review. The evidence was summarized by three independent researchers and the inconsistencies found were discussed until the final consensus. The extracted information was tabulated for data descriptive synthesis.

Two independent researchers assessed the methodological quality and risk of bias of selected studies using the JBI Appraisal Tools $^{(15)}$. To resolve the divergent data, the elements of the tool were used, promoting greater accuracy and minimizing bias. Analysis of results was carried out in a descriptive manner, with a summary of each of the studies included in this review being presented.

\section{RESULTS}

Database search identified 364 articles, of which ten made up the final sample, eight from CINAHL and two from Embase. From the reading of the selected articles, eleven articles were identified that were in their references, which in the reading and analysis by the two researchers, adequately met the study criteria, being added to the first result, totaling the sample of 20 articles included, as shown in Figure 1.

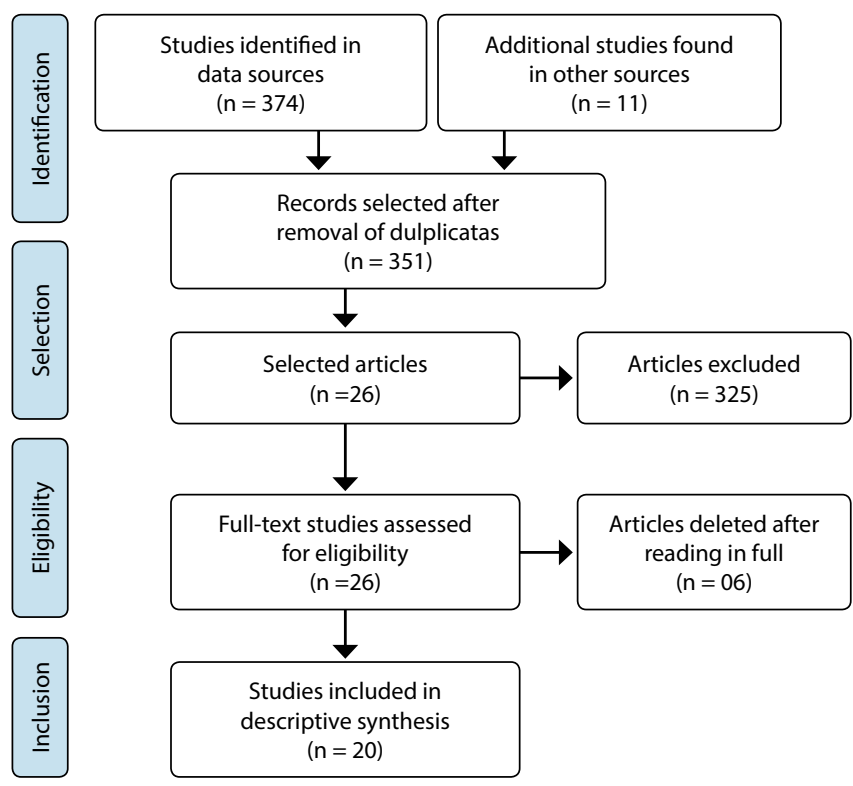

Figure 1- Flowchart, according to criteria of Preferred Reporting Items for Systematic Reviews and Meta-Analyses Extension for Scoping Reviews (PRISMA-SCR)

All primary studies included in the review were published in English, with publications on the subject starting in 2017 until the present day. The studies were mostly carried out in Belgium (11 studies - 55\%) and France (five studies - 25\%), including two publications from Finland (10\%), one publication originating in Japan and one from the Netherlands ( $5 \%$ each), respectively.

Among the selected articles, there was a predominance of cross-sectional studies (09; 45\%), followed by methodological studies $(05 ; 25 \%)$, with collection through survey or cross-sectional; longitudinal $(04 ; 20 \%)$ and survey type $(02 ; 10 \%)$.

The application of instruments to assess the methodological quality and risk of bias of the JBI Appraisal Tools made it possible to identify a low risk of bias in all the studies presented in the analysis.

Adding up all study participants, 23,734 fathers were approached, with a predominance of mothers in the studies, ranging from 50 to $100 \%$ of participation, and five studies (25\%) were carried out only with mothers. In Chart 1, the characteristics of the studies included in the analysis are described. 
Chart 1- Descriptive synthesis of selected articles $(n=21)$

\begin{tabular}{|c|c|c|c|c|c|}
\hline Title & $\begin{array}{c}\text { Country/ } \\
\text { Year }\end{array}$ & Objectives & $\begin{array}{l}\text { Design/ } \\
\text { Number of } \\
\text { participants }\end{array}$ & Outcomes & $\begin{array}{c}\text { Risk of } \\
\text { bias* (15) }\end{array}$ \\
\hline $\begin{array}{l}\text { 1. A step forward in } \\
\text { the conceptualization } \\
\text { and measurement } \\
\text { of parental burnout: } \\
\text { The Parental Burnout } \\
\text { Assessment (PBA) }{ }^{(16)}\end{array}$ & $\begin{array}{l}\text { Belgium, } \\
2018\end{array}$ & $\begin{array}{l}\text { Describe steps in } \\
\text { the construction of } \\
\text { an instrument to } \\
\text { measure and assess } \\
\text { parental burnout } \\
\text { and support its } \\
\text { conceptualization. }\end{array}$ & $\begin{array}{l}\text { Methodological } \\
\text { study through } \\
\text { survey/ } \\
901 \text { parents }\end{array}$ & $\begin{array}{l}\text { The instrument consisted of } 50 \text { items, with responses } \\
\text { in a Likert-type scale (related to frequency), divided } \\
\text { into three subscales: I- emotional exhaustion; } \\
\text { II - emotional distance and III - parents' loss of } \\
\text { fulfillment. } \\
\text { The instrument proved to be valid; however, it must } \\
\text { be suitable for different languages and cultures. } \\
\text { Parental psychological traits, parental factors and } \\
\text { family functioning contributed to the occurrence of } \\
\text { parental burnout. }\end{array}$ & $100 \%$ \\
\hline $\begin{array}{l}\text { 2. A theoretical and } \\
\text { clinical framework for } \\
\text { parental burnout: the } \\
\text { balance between risks } \\
\text { and resources }\left(\mathrm{BR}^{2}\right)^{(17)}\end{array}$ & $\begin{array}{l}\text { Belgium, } \\
2018\end{array}$ & $\begin{array}{l}\text { Test a theoretical } \\
\text { model of balance } \\
\text { between risk factors } \\
\text { and resources in } \\
\text { parental burnout. }\end{array}$ & $\begin{array}{l}\text { Longitudinal/ } \\
923 \text { parents }\end{array}$ & $\begin{array}{l}\text { The instrument reliably measured parents' balance } \\
\text { between risks and resources. } \\
\text { A strong relationship was identified between the } \\
\text { model and the Parental Burnout Assessment (PBA). } \\
\text { The model was found to predict parental exhaustion. } \\
\text { Risks and resources not specific to parenting predict } \\
\text { work and parental burnout. } \\
\text { Parenting-specific risks and resources only predict } \\
\text { parental burnout. } \\
\text { Imbalances between risk and resources are common } \\
\text { to all parents with parental burnout. }\end{array}$ & $100 \%$ \\
\hline $\begin{array}{l}\text { 3. Exhausted parents: } \\
\text { development and } \\
\text { preliminary validation } \\
\text { of the parental } \\
\text { burnout inventory }^{(6)}\end{array}$ & $\begin{array}{l}\text { Belgium, } \\
2017\end{array}$ & $\begin{array}{l}\text { Validate the parental } \\
\text { burnout construct } \\
\text { and measurement } \\
\text { instrument. }\end{array}$ & $\begin{array}{l}\text { Methodological } \\
\text { study through } \\
\text { survey/ } \\
2,102 \text { parents }\end{array}$ & $\begin{array}{l}\text { The parental burnout inventory showed adequate } \\
\text { validity and reliability; the } 22 \text { items had strong } \\
\text { psychometric properties. } \\
\text { There was a low correlation of parental burnout } \\
\text { with burnout, stress and depression, proving to be a } \\
\text { specific syndrome. } \\
2 \text { to } 12 \% \text { prevalence of parental burnout in the } \\
\text { sample. }\end{array}$ & $100 \%$ \\
\hline $\begin{array}{l}\text { 4. Validity of the } \\
\text { parental burnout } \\
\text { inventory among } \\
\text { Dutch employees }{ }^{(7)}\end{array}$ & $\begin{array}{c}\text { Netherlands, } \\
2018\end{array}$ & $\begin{array}{l}\text { Validate the PBA in } \\
\text { a sample of working } \\
\text { parents in the } \\
\text { Netherlands. }\end{array}$ & $\begin{array}{l}\text { Methodological } \\
\text { study through } \\
\text { cross-sectional } \\
\text { data collection/ } \\
627 \text { parents }\end{array}$ & $\begin{array}{l}\text { Low correlation between parental burnout, burnout, } \\
\text { stress, depression and experience of conflicts in the } \\
\text { family and at work. } \\
\text { Parental burnout: new and specific concept. } \\
\text { PBA: instrument with good consistency and reliability } \\
\text { to assess parental burnout. } \\
\text { Prevalence of parental burnout } 0.2 \%-0.3 \% \text { for } \\
\text { mothers and }<0.01 \% \text { for fathers. }\end{array}$ & $100 \%$ \\
\hline $\begin{array}{l}\text { 5. Differences in } \\
\text { parental burnout: } \\
\text { influence of } \\
\text { demographic factors } \\
\text { and personality of } \\
\text { parents and children }\end{array}$ & $\begin{array}{c}\text { France, } \\
2018\end{array}$ & $\begin{array}{l}\text { Replicate the PBA and } \\
\text { analyze the influence } \\
\text { of sociodemographic } \\
\text { factors and parent } \\
\text { and child personality } \\
\text { traits in detected } \\
\text { cases of parental } \\
\text { burnout. }\end{array}$ & $\begin{array}{l}\text { Longitudinal/ } \\
372 \text { parents }\end{array}$ & $\begin{array}{l}\text { Younger parents - higher personal achievement } \\
\text { scores and higher exhaustion scores. } \\
\text { The number of children was associated with greater } \\
\text { emotional distance between parents and children. } \\
\text { Parental traits - meticulousness and lack of emotional } \\
\text { control were at risk for burnout. } \\
\text { Children with lack of control and meticulousness - } \\
\text { associated with parental burnout. } \\
\text { High level of neuroticism associated with parents' } \\
\text { lower sense of accomplishment, greater exhaustion } \\
\text { and distance. } \\
\text { Parental personality influenced } 42.3 \% \text { of cases } \\
\text { of parental burnout and children's personality } \\
\text { contributed in } 13.8 \% \text { of cases. }\end{array}$ & $100 \%$ \\
\hline $\begin{array}{l}\text { 6. Preliminary } \\
\text { validation of Japanese } \\
\text { version of the parental } \\
\text { burnout inventory and } \\
\text { its relationship with } \\
\text { perfectionism }{ }^{(19)}\end{array}$ & $\begin{array}{l}\text { Japan, } \\
2018\end{array}$ & $\begin{array}{l}\text { Validate the Japanese } \\
\text { version of the PBA. }\end{array}$ & $\begin{array}{l}\text { Survey/ } \\
1,200 \text { parents }\end{array}$ & $\begin{array}{l}\text { Low correlation between parental burnout and } \\
\text { burnout, parental stress and depression. } \\
\text { Perfectionism at work was correlated with parental } \\
\text { burnout. } \\
\text { Prevalence of } 17.3 \% \text { of parental burnout (greater } \\
\text { in mothers than in fathers - } 21 \% \text { mothers and } 2.3 \% \\
\text { fathers). }\end{array}$ & $100 \%$ \\
\hline $\begin{array}{l}\text { 7. Development and } \\
\text { preliminary validation } \\
\text { of the maternal } \\
\text { burnout scale (MBS) } \\
\text { in French sample of } \\
\text { mothers: bifactorial } \\
\text { structure, reliability } \\
\text { and validity }{ }^{(20)}\end{array}$ & $\begin{array}{c}\text { France, } \\
2019\end{array}$ & $\begin{array}{l}\text { Develop and validate } \\
\text { an instrument for } \\
\text { measuring burnout } \\
\text { in mothers (Maternal } \\
\text { Burnout Scale - MBS). }\end{array}$ & $\begin{array}{l}\text { Methodological } \\
\text { study, with cross- } \\
\text { sectional data } \\
\text { collection/ } \\
\text { 1,950 mothers }\end{array}$ & $\begin{array}{l}\text { The MBS had good psychometric properties with } \\
\text { good overall and subscale internal consistency. } \\
\text { Prevalence of burnout in mothers: } 6.6 \% \text {. }\end{array}$ & $100 \%$ \\
\hline
\end{tabular}


Chart 1

\begin{tabular}{|c|c|c|c|c|c|}
\hline Title & $\begin{array}{c}\text { Country/ } \\
\text { Year }\end{array}$ & Objectives & $\begin{array}{l}\text { Design/ } \\
\text { Number of } \\
\text { participants }\end{array}$ & Outcomes & $\begin{array}{l}\text { Risk of } \\
\text { bias* (15) }\end{array}$ \\
\hline $\begin{array}{l}\text { 8. Is parental } \\
\text { burnout distinct } \\
\text { from job burnout } \\
\text { and depressive } \\
\text { symptomatology? }\end{array}$ & $\begin{array}{l}\text { Belgium, } \\
2020\end{array}$ & $\begin{array}{l}\text { Clarify the distinction } \\
\text { between the } \\
\text { concepts of parental } \\
\text { burnout, burnout } \\
\text { (work) and depressive } \\
\text { symptoms. }\end{array}$ & $\begin{array}{l}\text { Cross-sectional/ } \\
3,482 \text { parents }\end{array}$ & $\begin{array}{l}\text { There was a distinction between parental burnout } \\
\text { and burnout and depressive symptoms, and it was } \\
\text { found as consequences of parental burnout: child } \\
\text { violence and/or neglect and intention to leave work, } \\
\text { and none of these consequences were associated } \\
\text { with depressive symptoms. }\end{array}$ & $100 \%$ \\
\hline $\begin{array}{l}\text { 9. Validity of the } \\
\text { Finnish version of } \\
\text { the Parental Burnout } \\
\text { Assessment (PBA) }\end{array}$ & $\begin{array}{l}\text { Finland, } \\
2020\end{array}$ & $\begin{array}{l}\text { Validate the Finnish } \\
\text { version of the PBA } \\
\text { instrument. }\end{array}$ & $\begin{array}{l}\text { Methodological } \\
\text { study, through } \\
\text { survey/ } \\
1,688 \text { parents }\end{array}$ & $\begin{array}{l}\text { The instrument (PBA) had adequate psychometric } \\
\text { properties to measure parental burnout. } \\
\text { Parental burnout presented itself as a different } \\
\text { construct, with its specific characteristics. }\end{array}$ & $100 \%$ \\
\hline $\begin{array}{l}\text { 10. Exhausted parents: } \\
\text { sociodemographic, } \\
\text { child-related, parent- } \\
\text { related, parenting and } \\
\text { family functioning } \\
\text { correlates of parental } \\
\text { burnout }^{(23)}\end{array}$ & $\begin{array}{l}\text { Belgium, } \\
2018\end{array}$ & $\begin{array}{l}\text { Investigate risk } \\
\text { factors associated } \\
\text { with parental } \\
\text { burnout. }\end{array}$ & $\begin{array}{l}\text { Cross-sectional/ } \\
1,732 \text { countries }\end{array}$ & $\begin{array}{l}\text { Parental burnout is a complex and multifactorial problem. } \\
\text { - Risk factors: parental traits: neuroticism and } \\
\text { avoidance of excesses; parenting: restriction of roles; } \\
\text { family malfunction: exposure to conflict and family } \\
\text { disorganization. } \\
\text { - Protection factors: parental traits: emotional intelligence; } \\
\text { parenting: positive parenting and self-efficacy beliefs as } \\
\text { parents; satisfaction and agreement with partner (co- } \\
\text { parenting). }\end{array}$ & $100 \%$ \\
\hline $\begin{array}{l}\text { 11. Maternal burnout } \\
\text { syndrome: contextual } \\
\text { and psychological } \\
\text { associated factors }^{(24)}\end{array}$ & $\begin{array}{c}\text { France, } \\
2018\end{array}$ & $\begin{array}{l}\text { Explore influencing } \\
\text { contexts and } \\
\text { psychological factors } \\
\text { associated with } \\
\text { parental burnout. }\end{array}$ & $\begin{array}{l}\text { Cross-sectional/ } \\
304 \text { mothers }\end{array}$ & $\begin{array}{l}\text { Exhaustion percentage was detected - } 13.4 \% \text {; } \\
\text { depersonalization }-4.9 \% \text {; and parental ineffectiveness } \\
-7.4 \% \text {. } \\
\text { Parental burnout scores were strongly associated with } \\
\text { depressive symptoms, anxiety, stress and parental stress. } \\
\text { Parenting-oriented coping style was associated with } \\
\text { professional fulfillment. } \\
\text { Factors associated with burnout were: being employed; } \\
\text { working full time; and living without a partner. }\end{array}$ & $100 \%$ \\
\hline $\begin{array}{l}\text { 12. Feeling pressure to } \\
\text { be a perfect mother } \\
\text { relates to parental } \\
\text { burnout and career } \\
\text { ambitions }^{(25)}\end{array}$ & $\begin{array}{l}\text { Belgium, } \\
2018\end{array}$ & $\begin{array}{l}\text { Relate the pressure } \\
\text { of "being a perfect } \\
\text { mother" and parental } \\
\text { burnout and how } \\
\text { perfect motherhood } \\
\text { affects women's work. }\end{array}$ & $\begin{array}{l}\text { Survey/ } \\
169 \text { working } \\
\text { mothers }\end{array}$ & $\begin{array}{l}\text { Association between being a perfect mother and } \\
\text { emotional exhaustion. } \\
\text { Relationships mediated by parental stress. } \\
\text { Pressure to be a perfect mother has an indirect effect } \\
\text { on career ambitions and self-care. } \\
\text { Balance between work and family was associated } \\
\text { with lower career projections and ambitions. }\end{array}$ & $100 \%$ \\
\hline $\begin{array}{l}\text { 13. The big five } \\
\text { personality traits and } \\
\text { parental burnout: } \\
\text { protective and risk } \\
\text { factors }^{(26)}\end{array}$ & $\begin{array}{l}\text { Belgium, } \\
2017\end{array}$ & $\begin{array}{l}\text { Test the impact of } \\
\text { personality traits on } \\
\text { the occurrence of } \\
\text { parental burnout. }\end{array}$ & $\begin{array}{l}\text { Cross-sectional/ } \\
1,723 \text { countries }\end{array}$ & $\begin{array}{l}\text { Three personality traits were related to the } \\
\text { occurrence of parental burnout: neuroticism (higher } \\
\text { level associated with the occurrence); awareness (low } \\
\text { level associated with the occurrence); and sympathy } \\
\text { (lower levels associated with the occurrence). }\end{array}$ & $100 \%$ \\
\hline $\begin{array}{l}\text { 14. Risk factors for } \\
\text { parental burnout } \\
\text { among Finish } \\
\text { relatives: the role of } \\
\text { socially prescribed } \\
\text { perfectionism }\end{array}$ & $\begin{array}{l}\text { Finland, } \\
2020\end{array}$ & $\begin{array}{l}\text { Check the } \\
\text { association between } \\
\text { perfectionism, } \\
\text { sociodemographic } \\
\text { variables and } \\
\text { parental burnout. }\end{array}$ & $\begin{array}{l}\text { Cross-sectional/ } \\
1,729 \text { parents }\end{array}$ & $\begin{array}{l}\text { The following were associated with emotional } \\
\text { exhaustion: age of parents (younger parents), } \\
\text { unemployment, and poor financial conditions. } \\
\text { Perfectionism was associated with emotional } \\
\text { exhaustion. }\end{array}$ & $100 \%$ \\
\hline $\begin{array}{l}\text { 15. Depression, anxiety, } \\
\text { and quilt in mothers } \\
\text { with burnout of } \\
\text { preschool and school- } \\
\text { aged children: insight } \\
\text { from a cluster analysis } \\
\text { (28) }\end{array}$ & $\begin{array}{c}\text { France, } \\
2019\end{array}$ & $\begin{array}{l}\text { Explore the effects } \\
\text { of depression, } \\
\text { anxiety and guilt on } \\
\text { the occurrence of } \\
\text { parental burnout. }\end{array}$ & $\begin{array}{l}\text { Cross-sectional/ } \\
210 \text { mothers } \\
\text { diagnosed with } \\
\text { parental burnout }\end{array}$ & $\begin{array}{l}\text { Presence of severe symptoms of parental burnout in } \\
20 \% \text { of mothers and } 50 \% \text { had more than one child. } \\
\text { Parental burnout and anxiety were associated with } \\
\text { feelings of guilt. }\end{array}$ & $100 \%$ \\
\hline $\begin{array}{l}\text { 16. Regulation } \\
\text { between daily } \\
\text { exhaustion and } \\
\text { support in parenting: } \\
\text { a dyadic perspective }{ }^{(29)}\end{array}$ & $\begin{array}{l}\text { Belgium, } \\
2019\end{array}$ & $\begin{array}{l}\text { Investigate the } \\
\text { variation in parental } \\
\text { exhaustion on a } \\
\text { daily basis and the } \\
\text { relationship with } \\
\text { partners' perception } \\
\text { of support. }\end{array}$ & $\begin{array}{l}\text { Longitudinal/ } \\
194 \text { parents }\end{array}$ & $\begin{array}{l}\text { There was variation in feelings between couples on a daily } \\
\text { basis as well as daily regulation. } \\
\text { On the day a parent felt exhausted, high exhaustion was } \\
\text { detected in the partner. } \\
\text { The greater the exhaustion, the greater the perception of } \\
\text { support. } \\
\text { Mothers felt more exhausted and fathers were supportive. } \\
\text { Early intervention normalizes ambiguity, frustration and } \\
\text { exhaustion. } \\
\text { Greater motivation in being a good parent and partner } \\
\text { leads to greater fit in the relationship. } \\
\text { The study points to the need for couple therapy when } \\
\text { high levels of exhaustion are detected in both partners. }\end{array}$ & $100 \%$ \\
\hline
\end{tabular}




\begin{tabular}{|c|c|c|c|c|c|}
\hline Title & $\begin{array}{c}\text { Country/ } \\
\text { Year }\end{array}$ & Objectives & $\begin{array}{l}\text { Design/ } \\
\text { Number of } \\
\text { participants }\end{array}$ & Outcomes & $\begin{array}{c}\text { Risk of } \\
\text { bias* (15) }\end{array}$ \\
\hline $\begin{array}{l}\text { 17. Gender differences } \\
\text { in the nature, } \\
\text { antecedents and } \\
\text { consequences of } \\
\text { parental burnout }^{(30)}\end{array}$ & $\begin{array}{l}\text { Belgium, } \\
2020\end{array}$ & $\begin{array}{l}\text { Assess the effect } \\
\text { of gender on the } \\
\text { nature, antecedents } \\
\text { and consequences of } \\
\text { parental exhaustion. }\end{array}$ & $\begin{array}{l}\text { Cross-sectional/ } \\
874 \text { parents }\end{array}$ & $\begin{array}{l}\text { Mothers showed higher levels of strain than fathers as } \\
\text { well as higher levels of imbalance between risks and } \\
\text { resources. } \\
\text { However, the consequences of parental burnout } \\
\text { were more severe in fathers than in mothers - with } \\
\text { a higher frequency of child suicidal ideation, escape } \\
\text { and neglect. }\end{array}$ & $100 \%$ \\
\hline $\begin{array}{l}\text { 18. Maternal Burnout: } \\
\text { an exploratory study }{ }^{(31)}\end{array}$ & $\begin{array}{c}\text { France, } \\
2018\end{array}$ & $\begin{array}{l}\text { Detect prevalence of } \\
\text { burnout in mothers } \\
\text { and associated } \\
\text { factors. }\end{array}$ & $\begin{array}{l}\text { Cross-sectional/ } \\
263 \text { mothers }\end{array}$ & $\begin{array}{l}20 \% \text { prevalence of burnout in mothers. } \\
\text { The following were associated with maternal burnout: } \\
\text { having a child with a temper; having had postpartum } \\
\text { depression; anxiety; low satisfaction with personal } \\
\text { and professional life; and stress related to parenting. }\end{array}$ & $100 \%$ \\
\hline $\begin{array}{l}\text { 19. Consequences } \\
\text { of parental burnout: } \\
\text { its specific effect on } \\
\text { child neglect and } \\
\text { violence }^{(32)}\end{array}$ & $\begin{array}{l}\text { Belgium, } \\
2018\end{array}$ & $\begin{array}{l}\text { Assess the } \\
\text { consequences of } \\
\text { parental burnout. }\end{array}$ & $\begin{array}{l}\text { Cross-sectional/ } \\
1,551 \text { countries }\end{array}$ & $\begin{array}{l}\text { Parental burnout had similar effects to burnout (work) } \\
\text { in relation to sleep disorders. } \\
\text { Parental burnout caused stronger effects on couples' } \\
\text { conflicts and distancing from the partner. } \\
\text { Specific effects of parental burnout were considered: } \\
\text { child neglect and/or violence; escapes and suicidal } \\
\text { ideation. }\end{array}$ & $100 \%$ \\
\hline $\begin{array}{l}\text { 20. Parental burnout: } \\
\text { what is it and why } \\
\text { does it matter? } ?^{(33)}\end{array}$ & $\begin{array}{l}\text { Belgium, } \\
2017\end{array}$ & $\begin{array}{l}\text { Assess the } \\
\text { consequences of } \\
\text { parental burnout. }\end{array}$ & $\begin{array}{l}\text { Longitudinal } \\
\text { study/ } \\
1,740 \text { parents }\end{array}$ & $\begin{array}{l}\text { Parents who had parental burnout had a higher risk of } \\
\text { suicidal ideation and escapes, in addition to showing } \\
\text { violent behavior and neglecting the children. }\end{array}$ & $100 \%$ \\
\hline
\end{tabular}

${ }^{*}$ Risk of bias calculated by the JBI Appraisal Tools ${ }^{(15)}$.

All studies included in the review applied specific instruments to measure the variables of interest. For data collection on parental burnout, the most used was the Parental Burnout Assessment (17 studies $-85 \%$ ), in addition to the Short Version of Burnout Measure - Maslach in two studies (10\%), the MBS and the PBA Informant Form, in one study each (5\%), respectively.

To detect burnout cases (related to work) and distinguish parental burnout, the most used instrument was the Maslach Burnout Inventory (eight studies - 40\%). In order to differentiate between depression, different instruments were applied for data collection: The Hospital Anxiety and Depression Scale - used in four studies (20\%); Beck Depression Inventory (one study - 5\%); Todai Health Index Depression Scale (one study - 5\%); PHQ-8 (one study - 5\%) and the Bromley Postnatal Depression Scale (specific for postpartum depression) - used in one study (5\%). Depression was investigated in eight (40\%) studies with different instruments.

Parental stress was also assessed and measured with different instruments: Perceived Stress Scale (three studies - 15\%); Parental Stress Index Short (two studies - 10\%); Parental Stress Questionnaire (one study - 5\%); Parental Stress Inventory Short Form (one study - 5\%); and the Child-Rearing Stress Scale (one study $-5 \%)$. This variable was measured in eight studies (40\%), with validated and distinct instruments.

The Parental Neglect Scale and the Parental Violence Scale were used to detect cases of child neglect and violence in three studies (15\%). Parental personality traits were also assessed in four studies (20\%) through the instruments as follows: Big Three Perfectionism Scale (one study - 5\%); Big Five of Personality Traits (one study - 5\%); Multidimensional Perfectionism Scale (one study - 5\%); Neuroticism Subscale of The Big Five Inventory (one study; $5 \%$ ) and one study (5\%) assessed children's personality with the Ten Items Personality Inventory.

The following were also assessed: the balance between risks and resources in parental burnout (Balance between risks and resources $-\mathrm{BR}^{2}$ ); family agreement in parenting (Agreement Coparenting Subscale); family disorganization (Confusion Hubbub and Order Scale); antisocial behaviors (Marlowe-Crowne Social Desirability Scale); coping strategies (Ways of Coping Checklist); positive and negative emotions (PANAS Scale - Positive and Negative Affective Schedule); focus regulation (Regulatory Focus Scale); maternal custody (Maternal Gatekeeping); addiction (Comprehensive Inventory of Substance and Behavioral Addictions); perception of irritability (Carer's Irritability Questionnaire); job satisfaction (Quinn and Shepard's Job Satisfaction Index); partner support/support (Partner Parental Support Questionnaire); and presence of somatic complaints (Pennebaker Inventory of Limbic Languidness).

Information was also collected on: children's particularities (adopted children or children with chronic illnesses); parental factors; family functioning; conflicts and balance between family and work; career ambitions; guilt; postpartum depression; feelings of being a 'perfect mother'; suicidal ideation; escapes; sleep disorders; antisocial behaviors; conflicts with the partner, strangeness in the relationship with the partner; medication use; cortisol level.

The Parental Burnout Inventory showed adequate validity, reliability and consistency. The instrument that measures the balance between risks and resources in parental burnout (Balance between risks and resources $-\mathrm{BR}^{2}$ ) also proved to be reliable. The MBS, aimed at burnout in mothers, showed good psychometric properties and general consistency and in its subscales. Thus, the use of the three instruments is indicated depending on the objective of the study (diagnosis, detection of risk factors and sources of resources and exclusive diagnoses in mothers). It is noteworthy that all the methodological studies included concluded that parental burnout is a different problem from burnout (related to work), stress, depression and outcomes associated with family and/or work conflicts, due to its unique characteristics. 
The analysis of the articles included identified several risk factors for parental burnout, such as: parental personality traits (neuroticism; meticulousness; lack of emotional control and lack of avoidance of excesses); parental factors (restrictions due to parenthood); family functioning (conflicts and family disorganization); imbalance between risks and resources; depression; baby blues; stress; parental stress; perfectionism (including perfectionism at work and wanting to be a 'perfect mother'); low satisfaction with personal and/or professional life; guilt; unemployment; bad financial conditions; being employed and experiencing motherhood; work full time; live without a partner; young parents; have more than one child; children's personality traits, described as meticulousness; lack of emotional control; neuroticism and temper".

The protective factors described in the literature for parental burnout consisted of: parental personality traits (emotional intelligence; agreeableness; conscience; empathy and sympathy; perseverance); live positive parenting experience; feeling of self-efficacy in the role of parents; satisfaction, agreement on the principles of child rearing (co-parenting); partner support.

From the diversity of risk and protection factors, it appears that parental burnout is a complex and multifactorial problem. Studies analyzed showed a prevalence of $0.2 \%$ to $20 \%$ in fathers, being more frequent in mothers.

When considering the magnitude of parental burnout, analyzing its consequences, it was observed: sleep alterations; conflicts and distance between partners; intention to leave the job (dismissal); escapes and suicidal ideation and cases of child neglect and violence. It is noteworthy that individual and group psychotherapy proved to be an efficient tool in the treatment of diagnosed cases of parental burnout.

\section{DISCUSSION}

From the literature mapping, it was possible to identify appropriate instruments to diagnose cases of parental burnout, factors related to this occurrence, prevalence of symptoms among parents and their consequences if not diagnosed and treated.

Similar to the results presented in the review, validation studies with 430 parents in Chile ${ }^{(34)}$ and 614 families in China ${ }^{(3)}$ described adequate reliability and validity of the PBA to diagnose cases of parental burnout. Parental burnout has been assessed using the PBA in 40 countries and is the most widely used validated instrument for diagnosis ${ }^{(2)}$.

The instrument that measures risks and resources $\left(B^{2}\right)$ is also useful in these cases, as it is effective in detecting a balance between symptoms, family context and external support that parents use. As it is a complex and multifactorial syndrome, this instrument is useful in understanding the symptoms and contexts experienced ${ }^{(35)}$.

The MBS measures burnout only in mothers and was adequate for measuring symptoms in this population, but it is still little explored in the literature, although higher rates of parental burnout are found in mothers ${ }^{(34)}$. However, it should be noted that mothers are the majority of respondents in research on the subject ${ }^{(3,34,36)}$.

Parental burnout was presented as a different construct from burnout (related to work), as presented in this review. Burnout is a social and not an individual phenomenon, associated only with work relationships and not with parenthood ${ }^{(2)}$. In addition to presenting different characteristics, studies indicate that they did not find associations between burnout and the fact of having children ${ }^{(37-38)}$, which proves that these are different events. The only similarity between the two concepts is that they both cause sleep disorders ${ }^{(39)}$. It is noteworthy that sleep irregularity, short duration and fragmentation can affect neurobehavioral performance ${ }^{(39)}$ and the quality of life and health of those affected, which may predispose to both conditions.

Individuals with personality classified as hardiness - characterized by coping in the face of stressful situations, were associated with burnout. Having children was associated with people of hardiness personality, and this behavior was mainly changed after motherhood ${ }^{(40)}$, so that parenting can influence personality changes and have effects on work relationships. In this same sense, a Chinese study warns that parental emotional exhaustion can cause burnout in relation to work ${ }^{(35)}$, but it is not caused by it.

Parental burnout, as mentioned above, is also different from depression. Depression presents as characteristic signs and symptoms, loss of interest or sadness that persist for more than two weeks. Changes in sleep and appetite and lack of concentration are still common ${ }^{(41)}$. Data from the World Health Organization show that $4.4 \%$ of the world population suffers from depression, with women being more affected (5.1\%) than men (3.6\%). The same report shows that $3.6 \%$ of the population has an anxiety disorder and women are also more affected (4.6\%) than men $(2.6 \%)^{(42)}$.

A study points out that to protect their children, parents need to regulate their feelings and emotions. Positive emotions and feelings about parenting contribute to positive effects on child development. However, a study with 347 parents pointed out that the pressure not to demonstrate/externalize negative emotions and feelings requires daily effort and can deplete emotional resources, increasing the vulnerability to the development of parental burnout ${ }^{(36)}$.

A population study with 4,875 Australian mothers, followed up at birth, at one and ten years after delivery, identified five different mental health trajectories in the mothers: $66.8 \%$ had minimal psychological changes; $22 \%$ had subclinical symptoms of change; $3.9 \%$ showed changes early; $3.1 \%$ symptoms appeared and increased over time, and $4.8 \%$ had symptoms of persistent changes over the ten years. Among mothers who had changes that increased over time, there was an association with social and economic disadvantages and stress level. Among mothers who had persistent symptoms, there was an association with a diagnosis of depression and having had at least three or more events considered stressful in their lives in the last year ${ }^{(43)}$, showing the impact of parenthood on mothers' mental health and vice versa.

A study with 210 Mexican mothers sought to identify an association between difficult childhood temperament and signs of depression and/or anxiety in mothers. The results showed that mothers with signs of depression or anxiety before childbirth maintained the condition after childbirth and were also the ones who classified their children as "difficult". The emergence of anxiety after birth was associated with children's temper ${ }^{(44)}$. Similarly, children's behavior classified as difficult behaved as a risk factor for parental burnout. 
A study with 795 Dutch mothers showed that mothers with two or more children have more self-efficacy in the role of mother and lower levels of anxiety ${ }^{(45)}$ than mothers who have only one child, demonstrating the impact of pressure on being a 'good mother' that permeates the first parental experience.

A follow-up study carried out in Australia with 32 dyads (mother and child), at 30 weeks and 18 months postpartum, sought to identify whether symptoms of depression and maternal self-criticism increased after childbirth. High levels of anxiety and self-criticism were associated with greater attachment to infants. In women with changes in mental health that emerged postpartum, loss of control and autonomy associated with selfcriticism, greater risk of changes in mental health and the risk of loss of the bond were detected ${ }^{(46)}$.

A randomized controlled study of 452 women found that uncomplicated interventions such as support films and 24-hour hotline help with parenting questions significantly reduced postpartum stress among first-time mothers. These measures prove that through simple strategies it is possible to provide a healthy support network that contributes to the maintenance of maternal psychological well-being ${ }^{(47)}$.

As portrayed in the review, parental burnout is a complex syndrome that involves multiple factors and requires a network approach, i.e., sick parents need to be seen within the family context, as the change involves the family as a whole ${ }^{(35)}$.

Women who are financially dependent on their spouses and superficial and unstable relationships were also associated with higher rates of parental burnout. In turn, when she feels supported and there is real help from partners in parenting, mothers tend to have less marital and parental conflicts, proving to be a protective factor ${ }^{(34)}$. A study with Chinese families also showed an association between emotional exhaustion and marital dissatisfaction for both spouses. Parents' emotional exhaustion was associated with self-dissatisfaction, while maternal exhaustion was associated with feelings of sadness and loneliness expressed by the children. Both parents were exhausted when their children had antisocial behaviors and parental burnout was associated with parental neuroticism ${ }^{(3)}$.

The prevalence of parental burnout found ranged from 0.2 to $20 \%$ in the studies included in the review, most frequently in mothers. A multicenter study carried out in 40 countries indicates an average prevalence of 7 to $8 \%{ }^{(2)}$.
Finally, there was an association between the feeling of anger and parental burnout, which, as a chronic problem, predicts the experience and expression of anger towards children ${ }^{(2)}$, and as studies have shown, it can result in child neglect or violence ${ }^{(35)}$, with negative impacts on the family experience and on children's physical and emotional development.

A clinical trial with 142 parents sought to analyze the effects of individual and group psychotherapy as a treatment for cases of parental burnout. There was no difference between treatment modalities; however, psychotherapy reduced parental burnout symptoms by $37 \% ; 29 \%$ negative emotions; $35 \%$ child neglect and violence; and the cortisol level at $52 \%$. Parents undergoing therapy showed an $18 \%$ increase in positive feelings, being considered an efficient intervention tool, regardless of the modality it is offered ${ }^{(48)}$, presenting itself as a viable and effective alternative for treatment.

\section{Study limitations}

It is understood as a limitation of the study the fact that it is still an incipient topic, with production based on recent studies. Thus, protective and risk factors are under investigation as well as instruments for their measurement and the possibility of treatments. Another limitation is that most studies are focused on the maternal experience of parental burnout, since the effects on parents may not be measured or applicable and an instrument for both may not be the most suitable for maternal diagnosis.

\section{Contributions to health}

Given the magnitude of parental burnout and its negative impacts on the experience of parenting and family relationships, it is suggested to expand studies, debates and dissemination on the subject.

\section{CONCLUSIONS}

Parental burnout is a complex and multifactorial problem, a recent topic of studies in several countries and, if left untreated, it can have serious consequences in marital life, in work relationships and in cases of child neglect and violence. Due to its magnitude and impact on the experience of parenting, it needs to be widely discussed and explored.

\section{REFERENCES}

1. Junewicz A, Billick SB. Nature, nurture, and attachment: implications in light of expanding definitions of parenthood. Psychiatr Q. 2018;89(3):511-9. https://doi.org/10.1007/s11126-017-9554-3

2. Maslach C, Schaufeli WB, Leiter MP. Job burnout. Annu Rev Psychol. 2001;52:397-422. https://doi.org/10.1146/annurev.psych.52.1.397

3. Prikhidko A, Swank JM. Exhausted parents experience of anger: the relationship between anger and burnout. Fam J. 2020;28(3);283-9. https://doi. org/10.1177/1066-480720933543.

4. Cheng H, Wang W, Wang S, Li Y, Liu X, Li Y.Validation of a Chinese version of the parental burnout assessment. Front Psychol. 2020;11:321. https:// doi.org/10.3389/fpsyg.2020.00321

5. Brown SM, Doom JR, Lechuga-Peña S, Watamura SE, Koppels T. Stress and parenting during the global covid-19 pandemic. Child Abuse Negl. 2020;110(Pt2):104699. https://doi.org/10.1016/j.chiabu.2020.104699 
6. Roskam I, Raes M-E, Mikolajczak M. Exhausted parents: development and preliminary validation of the parental burnout inventory. Front Psychol. 2017;8:163. https://doi.org/10.3389/fpsyg.2017.00163

7. Van Bakel HJA, Van Engen ML, Peters P.Validity of the parental burnout inventory among Dutch employees. Front Psychol. 2018;9:697. https://doi. org/10.3389/fpsyg.2018.00697

8. Griffith AK. Parental burnout and child maltreatment during the covid-19 pandemic. J Fam Violence. 2020:1-7. https://doi.org/10.1007/ s10896-020-00172-2

9. Gérain P, Zech E. Does informal caregiving lead to parental burnout?: comparing parents having (or not) children with mental and physical issues. Front Psychol. 2018;9:884. https://doi.org/10.3389/fpsyg.2018.00884

10. Hubert S, Aujoulat I. Parental burnout: when exhausted mothers open up. Front Psychol. 2018;9:1021. https://doi.org/10.3389/fpsyg.2018.01021

11. Colquhoun HL, Levac D, O'Brien KK, Straus S, Tricco AC, Perrier L, et al. Scoping reviews: time for clarity in definition, methods, and reporting. J Clin Epidemiol. 2014;67(12):1291-4. https://doi.org/10.1016/j.jclinepi.2014.03.013

12. Peters MDJ, Godfrey CM, Khalil H, Mclnerney P, Parker D, Soares CB. Guidance for conducting systematic scoping reviews. Int J Evid Based Healthc. 2015;13(3):141-6. https://doi.org/10.1097/XEB.0000000000000050

13. Tricco AC, Lillie E, Zarin W, O'Brien KK, Colquhoun HL, Levac D, et al. PRISMA extension for scoping reviews (PRISMA-ScR): checklist and explanation. Ann Intern Med. 2018;169(7):467-73. https://doi.org/10.7326/M18-0850

14. Lockwood C, Tricco AC. Preparing scoping reviews for publication using methodological guides and reporting standards. Nurs Health Sci. 2020;22(1):1-4. https://doi.org/10.1111/nhs.12673.

15. Joanna Briggs Institute. Joanna Briggs institute reviewers' manual: 2014 edition [Internet]. Adelaide: University of Adelaide; 2020[cited 2020 Oct 08]. Available from: https://nursing.Isuhsc.edu/JBI/docs/ReviewersManuals/ReviewersManual.pdf

16. Roskam I, Brianda M-E, Mikolajczak M. A step forward in the conceptualization and measurement of Parental Burnout: the parental burnout assessment (PBA). Front Psychol. 2018;9:758. https://doi.org/10.3389/fpsyg.2018.00758

17. Mikolajczak M, Roskam I. A theoretical and clinical framework for Parental Burnout: the balance between risks and resources (BR2). Front Psychol. 2018;9:886. https://doi.org/10.3389/fpsyg.2018.00886

18. Le Vigouroux S, Scola C. Differences in parental burnout: influence of demographic factors and personality of parents and children. Front Psychol. 2018;9:887. https://doi.org/10.3389/fpsyg.2018.00887

19. Kawamoto T, Furutani K, Alimardani M. Preliminary validation of Japanese version of the parental burnout inventory and its relationship with perfectionism. Front Psychol. 2018;9:970. https://doi.org/10.3389/fpsyg.2018.00970

20. Sánchez-Rodríguez R, Callahan S, Séjourné N. Development and preliminary validation of the maternal burnout scale (MBS) in a French sample of mothers: bifactorial structure, reliability, and validity. Arch Womens Ment Health. 2019;23(4):573-83. https://doi.org/10.1007/s00737-019-00993-1

21. Mikolajczak M, Gross JJ, Stinglhamber F, Norberg AL, Roskam I. Is parental burnout distinct from job burnout and depressive symptomatology? Clin Psychol Sci. 2020;8(4):673-89. https://doi.org/10.1177/2167702620917447

22. Aunola K, Sorkkila M, Tolvanen A. Validity of the finnish version of the parental burnout assessment (PBA). Scand J Psychol. 2020;61 (5):714-22. https://doi.org/10.1111/sjop.12654

23. Mikolajczak M, Raes M-E, Avalosse H, Roskam I. Exhausted parents: sociodemographic, child-related, parent- related, parenting and familyfunctioning correlates of Parental Burnout. J Child Fam Stud. 2017;27:602-14. https://doi.org/10.1007/s10826-017-0892-4

24. Lebert-Charron A, Dorard G, Boujut E, Wendland J. Maternal Burnout syndrome: contextual and psychological associated factors. Front Psychol. 2018;9:885. https://doi.org/10.3389/fpsyg.2018.00885

25. Meeussen L, Van Laar C. Feeling pressure to be a perfect mother relates to Parental Burnout and career ambitions. Front Psychol. $2018 ; 9: 2113$. https://doi.org/10.3389/fpsyg.2018.02113

26. Le Vigoroux S, Scola C, Raes M-E, Mikolajczak M, Roskam I. The big five personality traits and parental burnout: protective and risk factors. Personal Individ Dif. 2017;119:216-9. https://doi.org/10.1016/j.paid.2017.07.023

27. Sorkkila M, Aunola K. Risk factors for parental burnout among finnish parents: the role of socially prescribed perfectionism. J Child Fam Stud. 2019;29:648-59. https://doi.org/10.1007/s10826-019-01607-1

28. Sánchez-Rodríguez R, Orsini E, Laflaquière E, Callahan S, Séjourné N. Depression, anxiety, and guilt in mothers with burnout of preschool and school-aged children: insight from a cluster analysis. J Affect Disord. 2019;259:244-50. https://doi.org/10.1016/j.jad.2019.08.031

29. Gillis A, Roskam I. Regulation between daily exhaustion and support in parenting: a dyadic perspective. Int J Behav Dev. 2020;44(3):226-35. https:// doi.org/10.1177/0165025419868536

30. Roskam I, Mikolajczak M. Gender differences in the nature, antecedents and consequences of parental burnout. Sex Roles. 2020;83:485-93. https:// doi.org/10.1007/s11199-020-01121-5

31. Sejourne N, Sanchez-Rodriguez R, Leboullenger A, Callahan S. Maternal burn-out: an exploratory study. J Reprod Infant Psychol. 2018;36(3):276-88. https://doi.org/10.1080/02646838.2018.1437896

32. Mikolajczak M, Brianda ME, Avalosse H, Roskam I. Consequences of parental burnout: its specific effect on child neglect and violence. Child Abuse Negl. 2018;80:134-45. https://doi.org/10.1016/j.chiabu.2018.03.025 
33. Mikolajczak M, Gross JJ, Roskam I. Parental Burnout: what is it and why does it matter?. Clin Psychol Sci. 2019;7(6):1319-29. https://doi. org/10.1177/2167702619858430

34. Peréz-Diaz PA, Oyarce Cádiz D. Burnout parental en Chile y género: un modelo para comprender el burnout en madres chilenas. Rev Psicol (Santiago). 2020;29(1):12-25. https://doi.org/10.5354/07-19-0581.2020.57987

35. Blanchard MA, Heeren A. Why we should move from reductionism and embrace a network approach to parental burnout. New Dir Child Adolesc Dev. 2020;2020(174):159-68. https://doi.org/10.1002/cad.2037

36. Lin GX, Hansotte L, Szcygiel D, Meussen L, Roskam I, Mikolajczak M. Parenting with a smile: display rules, regulatory effort and burnout parental. J Soc Pers Relat. 2021; 38(9):2701-2721. https://doi.org/10.1177/02654075211019124

37. Porciuncula AM, Venâncio AS, Silva CMFP. Burnout syndrome in family health strategy managers. Cienc Saude Colet. 2020;25(4):1555-66. https:// doi.org/10.1590/1413-81232020254.22072018

38. Leite TIA, Fernandes JPC, Araújo FLC, Pereira XBF, Azevedo SM, Lucena EES. Prevalence and factors associated with burnout among university professor. Rev Bras Med Trab. 2019;17(2):170-9. https://doi.org/10.5327/z1679443520190385

39. McBean AL, Montgomery-Downs HE. Timing and variability of postpartum sleep in relation to daytime performance. Physiol Behav. 2013;122(2):134-9. https://doi.org/10.1016/j.physbeh.2013.09.003

40. Silva-Jr RF, Alves ECS, Santos KO, Santos SP, Barbosa HA, Siqueira LG, et al. Hardy personality and associated factors in health professionals active in services that treat critical patients. Cienc Saude Colet. 2020; 25(1):199-209. https://doi.org/10.1590/1413-8123202051.29442019

41. World Health Organization. mhGAP intervention guide for mental, neurological and substance use disorders in non-specialized health settings: mental health gap action programme (mhGAP): version 2.0 [Internet]. Geneva:WHO; 2016[cited 2020 Nov 18]. Available from: https://www.who. int/publications/i/item/mhgap-intervention-guide---version-2.0

42. World Health Organization. Depression and other common mental disorders: global healh estimates [Internet]. Geneva:WHO; 2017[cited 2020 Nov 18]. Available from: https://www.who.int/mental_health/management/depression/prevalence_global_health_estimates/en/

43. Wajid A, Kingston D, Bright KS, Mughal MK, Charrois EM, Giallo R. Psychosocial factors associated with trajectories of maternal psychological distress over a 10-year period from the first year postpartum: an Australian population-based study. J Afecct Disord. 2020;263:31-8. https://doi. org/10.1016/j.jad.2019.11.138

44. Nieto L, Lara MA, Navarrete L, Manzo G. Infant temperament and perinatal depressive and anxiety symptons in Mexican women. Sex Reprod Healthc. 2019;21:39-45. https://doi.org/10.1016/j.srhc.2019.19.05.005

45. Cassé JFH, Oosterman M, Volling BL, Schuengel C. First-time motherhood experiences and the decision to have a second child. J Fam Issues. 2018;39(3):555-78. https://doi.org/10.1177/019.2513X16662100

46. Brassel A, Townsend ML, Pickard JA, Grenyer BFS. Maternal perinatal mental health: association with bonding, mindfulness and self-criticism at 18 months postpartum. Infant Ment Health J. 2020;41(1):69-81. https://doi.org/10.1002/imhj.21827

47. Osman H, Saliba M, Chaaya M, Naasan G. Interventions to reduce postpartum stress in first-time mothers: a randomized-controlled trial. BMC Womens Health. 2014;14:125. https://doi.org/10.1186/1472-6874-14-125

48. Brianda ME, Roskam I, Gross JJ, Frassen A, Kapala F, Gérard F, et al. Treating parental burnout: impact of two treatment modalities on burnout symptoms, emotions, hair cortisol, and parental neglect and violence. Psychother Psychosom. 2020;89(5):330-2. https://doi. org/10.1159/000506354 